\title{
The Influence of Freezing Rates on Bovine Pericardium Tissue Freeze-Drying
}

\author{
Camila Figueiredo Borgognoni ${ }^{1}$, Virgilio Tattini Junior ${ }^{1}$, Ana Maria Irene Bartolomeu \\ Ayrosa $^{1}$, Bronislaw Polakiewicz, Adolfo Alberto Leirner ${ }^{2}$, Marina Junko Shiotsu \\ Maizato $^{2}$, Olga Zazuco Higa ${ }^{3}$, Marisa Masumi Beppu ${ }^{4}$ and Ronaldo Nogueira de Moraes \\ Pitombo $^{1 *}$ \\ Faculdade de Ciências Farmacêuticas; Universidade de São Paulo; 05315-970; São Paulo - SP - Brasil. ${ }^{2}$ Instituto \\ do Coração; Faculdade de Medicina de São Paulo; São Paulo - SP - Brasil. ${ }^{3}$ Instituto de Pesquisas Energéticas e \\ Nucleares; São Paulo - SP - Brasil. ${ }^{4}$ Faculdade de Engenharia Química; Universidade de Campinas; Campinas - \\ SP - Brasil
}

\begin{abstract}
The bovine pericardium has been used as biomaterial in developing bioprostheses. Freeze-drying is a drying process that could be used for heart valve's preservation. The maintenance of the characteristics of the biomaterial is important for a good heart valve performance. This paper describes the initial step in the development of a bovine pericardium tissue freeze-drying to be used in heart valves. Freeze-drying involves three steps: freezing, primary drying and secondary drying. The freezing step influences the ice crystal size and, consequently, the primary and secondary drying stages. The aim of this work was to investigate the influence of freezing rates on the bovine pericardium tissue freeze-drying parameters. The glass transition temperature and the structural behaviour of the lyophilized tissues were determined as also primary and secondary drying time. The slow freezing with thermal treatment presented better results than the other freeze-drying protocols.
\end{abstract}

Key words: Freeze-drying, freezing, bovine pericardium

\section{INTRODUCTION}

Almost 30 years after the introduction of valvular prostheses, patients worldwide are receiving cardiac valve substitutes each year. Among these, the bovine pericardium has become a commonly accepted device for heart valve replacement (Chaikof, 2007).

Freeze-drying can be used in preservation of bioprosthesis and in tissue engineering (James et al., 1991; Buttafoco et al., 2006; Faraj et al., 2007).
The advantages of freeze-drying in clinical practice include a decrease of surgical time and surgical morbidity, assessment of the graft size and shape prior to operation and storage of tissue grafts in operating rooms (Webster and Werner, 1983).

When applied to biological (human or animal) tissues, freeze-drying process allows them to be preserved dried, making manipulation and storage easier. Freeze-drying does not possess inherent to the process sterilization action, although the equipment can be sterilized and operated under

*Author for correspondence: pitombo@usp.br 
aseptic conditions but the freeze-dried material allows gamma rays sterilization and other ways to guarantee its effective sterilization which is necessary to eliminate slow viruses when the material is destined for medical or surgical applications.

Freeze-drying associated with chemical treatment is a potential route of bovine pericardium bioprosthetic heart valves preparation (Mello et al., 2006). This hypothesis is sustained by the fact that non-freeze-dried samples show calcium phosphate deposits, in contrast with the freezedried ones (Aimole et al., 2007). Besides the benefits related to calcification, the freeze-drying can potentially promote less cytotoxicity and residual aldehydes in glutaraldehyde-treated bovine pericardium (Maizato et al., 2003).

Freeze-drying is a technique where freezable water is removed from a frozen material first by sublimation (primary drying), followed by desorption of the unfrozen water, under reduced pressure (secondary drying). Freeze drying is a drying process, i.e., a multistage operation, in which each step is critical. Some considerations about the moisture content of product are used to justify the drying phenomenon (Biazus et al., 2005).

The freezing stage is a critical step because it influences the ice crystal size and, consequently, the primary and secondary drying stages (Doillon et al., 1986; Patapoff and Overcashier, 2002; O'Brien et al., 2004). In the primary drying, the ice crystals' sizes must be large to obtain the shortest time. But in the secondary drying, these sizes must be smaller to offer a large specific surface area of the dried matrix in order to improve desorption of unfrozen water from the pores surface of the amorphous matrix (Jennings, 1999).

Annealing is a process step in which samples are maintained at a specified subfreezing temperature for a defined period of time. In general, this temperature is between the glass transition temperature $\left(\mathrm{T}_{\mathrm{g}}{ }^{\prime}\right)$ and the melting temperature (Searles et al., 2001). It maximizes the crystallization of water that was trapped in the vitreous phase during the cooling step. An annealing treatment just after the freezing step during a few hours by reheating the product generally confers a certain homogenization to the ice crystals sizes' distribution. Thermal treatment by annealing has been studied by many researchers (Hawe and Friess, 2006; Searles et al., 2001;
Abdelwahed et al., 2006). It is a process in which samples are maintained at a specified freezing temperature for a period of time.

One key parameter that has been identified as crucial to the understanding of the lyophilization process is the glass transition temperature of the given product. Generally, the process temperature is set below the sub-ambient $\mathrm{T}_{\mathrm{g}}$ ' of the product during primary drying in order to avoid the 'collapse' during lyophilization. The glass transition temperature of any amorphous substance is defined as the temperature range where the specific heat $(\mathrm{Cp})$ changes in a stepwise manner. Different temperatures may be chosen to characterize this transition: the onset point $\left(\mathrm{T}_{\mathrm{g} 0}\right)$, the mid-point of the heat capacity change $\left(\mathrm{T}_{\mathrm{gm}}\right)$ or the end-point $\left(\mathrm{T}_{\mathrm{ge}}\right)$. In addition to the glass transition temperature, the magnitude of the change in heat capacity $(\Delta \mathrm{Cp})$ at $\mathrm{T}_{\mathrm{g}}{ }^{\prime}$ along with the occurrence of any recrystallization events may have a major effect on the successful avoidance of the collapse of the product during processing. Thus, an analytical technique is required which yields accurate, sensitive and reproducible data on $\mathrm{T}_{\mathrm{g}}{ }^{\prime}$ and recrystallization transformations in the subambient temperature regions. This information is valuable in the generation of a 'pharmaceutically elegant' freeze-dried product.

Differential scanning calorimetry (DSC) provides a means of addressing the key issues surrounding the production of a successful lyophilized material. It provides the necessary high degree of sensitivity, resolution and stable subambient performance necessary to observe the weak glass transition(s) and recrystallization events associated with products undergoing lyophilization.

For simple aqueous solutions, glass transition temperature was shown to take place $1-2^{\circ} \mathrm{C}$ below the collapse temperature $\left(\mathrm{T}_{\mathrm{c}}\right)$ (Pikal and Shah, 1990). $T_{c}$ is also often considered as close to the glass transition temperature, which in turn is usually measured by DSC (Levine and Slade, 1988; Chang and Randall, 1992). Collapse temperatures are measured by direct microscopic observation in a stage at low temperature and low pressure simulating freeze-drying conditions. Actually, a temperature above which the 'mobility' of the system is observed on an experimental time scale characterizes the glass transition.

However, $\mathrm{T}_{\mathrm{c}}$ cannot be considered as identical to the glass transition temperature. Glass transition is measured in closed systems after freezing (and 
before melting), whereas collapse is a dynamic phenomenon taking place during freeze-drying (Nail et al., 2002).

Pericardium tissue is composed mainly of collagen type I (Naimark et al., 1992). Raman spectroscopy is a very powerful tool for studying the structure and molecular interactions of many complex molecules. Raman spectroscopy has been widely used to study the structure and dynamics of a variety of biological macromolecules (Spiro, 1987). Collagen is the principal structure protein of tissue, including tendon, blood vessels, skin, bone and tissue membranes (e.g. pericardium). These proteins can undergo qualitative and quantitative changes under various stress conditions (e.g. freezing, drying and storage). Because Raman spectroscopy offers the possibility for examining these changes in situ, several authors have studied the spectra of various collagenous biological substances such as calcified tissue (Walton et al., 1970), bovine Achilles tendon (Frushour et al., 1975) and glutaraldehyde treated pericardium tissue (Jastrzebska et al., 2003).

One of the greatest advantages of this technique is its ability to provide information about the structure and interactions of biomolecules in their microenvironment within intact cells and tissue. The technique is not destructive and does not require homogenization, extraction or the use of dyes, labels or other contrast-enhancing agents.

The objective of this work was to characterize the thermal behavior of bovine pericardium, investigate the influence of freezing rates and annealing on the secondary structure of the tissue and its influence on the freeze-drying times.

\section{MATERIALS AND METHODS}

\section{Materials}

Bovine pericardium was obtained from a local slaughterhouse, where it was cleaned to remove fat and transported to the laboratory in a saline solution $(0.9 \% \mathrm{w} / \mathrm{v} \mathrm{NaCl})$. Afterwards, the tissue was immersed into glycerin until the analyses. Preceding the analyses, the samples were washed in saline solution $(0.9 \% \mathrm{w} / \mathrm{v} \quad \mathrm{NaCl})$ using continuous stirring for 15 minutes and repeated three times to remove the excess of glycerin.

\section{Freezing and freeze-drying}

Freeze-drying runs were performed at an FTS Systems freeze-dryer, model TDS-00209-A, microprocessor controlled tray dryer (Dura-Stop, Dura-Dry-MP). Samples of $3 \mathrm{~cm}^{2}$ were placed on Petri dishes and submitted to slow freezing $\left(2^{\circ} \mathrm{C} / \mathrm{min}\right)$ on trays until product temperature reach $-50^{\circ} \mathrm{C}$ and fast freezing $\left(30^{\circ} \mathrm{C} / \mathrm{min}\right)$ by immersion in liquid nitrogen (a thermopar was inserted into a sample to determine the final temperature).

When the thermal treatment by annealing was applied, samples were first frozen (slow or fast freezing). Then annealing was applied by heating the frozen samples to $-20^{\circ} \mathrm{C}$ and the temperature was held for $1 \mathrm{~h}$ at this fixed temperature. Finally, the samples were cooled to $-50^{\circ} \mathrm{C}$ and the samples were freeze-dried. Primary drying was conducted at a shelf temperature of $-5^{\circ} \mathrm{C}$ and a pressure of $160 \mathrm{mTorr}$. For secondary drying the shelf temperature was increased to $25^{\circ} \mathrm{C}$ at the same pressure.

\section{Water content determination}

The residual moisture of freeze-dried samples was obtained by Computrac Vapor Pro RX equipment (Arizona Instrument) at a constant temperature of $100^{\circ} \mathrm{C}$.

\section{Freeze-drying microscopy}

Collapse temperatures of bovine pericardium tissues were measured by using a freeze-drying cryo-stage (FDCS 196, Linkam Scientific Instruments, Surrey, U.K.) equipped with a liquid nitrogen cooling system (LNP94/2, Linkam) and a programmable temperature controller (TMS94, Linkam), which allowed heating and cooling rates ranging between 0.01 and $130^{\circ} \mathrm{C} \mathrm{min}^{-1}$. With a vacuum pump (Edwards E2M1.5, Linkam), a pressure as low as $0.5 \mathrm{~Pa}$ could be achieved, and a Pirani gauge monitored pressure. The stage was calibrated for temperature measurement with aqueous solutions of $\mathrm{NaCl}$ (eutectic melting temperatures of $-21.1^{\circ} \mathrm{C}$ ). The sample was placed on a 16-mm quartz cover slip (Linkam) in order to minimize vertical temperature gradients (quartz has a thermal conductivity much higher than glass), and another glass cover slip was placed on the top. Silicone oil was used between the microscope stage and the quartz cover slip in order to improve the thermal contact between the sample and the temperature-controlled plate. A metallic 
spacer, placed between the cover slips, helped to maintain the sample thickness almost constant between each two successive experiences. The sample was frozen to $-100^{\circ} \mathrm{C}$ and the system was evacuated to a pressure of about $1 \mathrm{~Pa}$. Direct observation of freezing and freeze-drying was done by using a Nikon Elipse E600 (Nikon, Japan) polarized microscope with a condenser extension lens (Linkam).

\section{Glass transition temperature determination}

The DSC system used to determine the glass transition temperature was a Seiko 220C differential scanning calorimeter (DSC) (Seiko Instruments, Horsham, PA), cooled by liquid nitrogen and a Seiko DSC 5200 Data Station. The sample $(30 \mathrm{mg})$ was sealed in a standard aluminum pan and a similar empty pan was used as reference. The calorimeter was calibrated for temperature and enthalpy with $n$-dodecane (transition temperatures of $-9.65^{\circ} \mathrm{C}$ ). The sample was cooled from 25 to $-120^{\circ} \mathrm{C}$ using different cooling rates $\left(1,2,10\right.$ and $\left.30^{\circ} \mathrm{C} / \mathrm{min}\right)$ and $5^{\circ} \mathrm{C} / \mathrm{min}$. during the warming stage. The samples was cooled to $-120^{\circ} \mathrm{C}$, then were heated $\left(5^{\circ} \mathrm{C} / \mathrm{min}\right)$ to $-20^{\circ} \mathrm{C}$ with isothermal (60 minutes) and cooled again to $-120^{\circ} \mathrm{C}$.

\section{Raman spectral analysis}

The secondary structure of native and freeze-dried bovine pericardium tissues were determined by FT-RAMAN spectroscopy using a BRUKER FRA 106/S Raman module on an IFS 28/N. All spectra were the average of 4000 scans at $4 \mathrm{~cm}^{-1}$ resolution. All the experiments were performed at room temperature $\left(25^{\circ} \mathrm{C}\right)$. Spectral intensity was calibrated using the $\mathrm{C}-\mathrm{H}$ vibrational modes as a convenient internal standard, since collagen was practically the only source of the C-H Raman signal.

\section{RESULTS AND DISCUSSION}

Figs. 1A and 1B represented the DSC curves obtained during the cooling of bovine pericardium tissue. An exothermic peak was observed during cooling the sample at different cooling rates: $14.2^{\circ} \mathrm{C}$ and $-18.5^{\circ} \mathrm{C}$ for slow cooling rate and fast cooling rate, respectively. These peaks were related tissue. The knowledge of this thermal behavior has great impact on the freeze-drying parameters' development, since the crystallization temperature induces directly the distribution, size and geometrical characteristics of the ice crystals formed into the sample. These parameters are closed related with the ice sublimation rate during the primary drying.

After the determination of crystallization temperature, the sample was cooled until it reached the final temperature of $-120^{\circ} \mathrm{C}$. From Fig. $2 \mathrm{~A}$, the $\mathrm{T}_{\mathrm{g}}$, value from native bovine pericadium was determined. The glass transition was well defined and confirmed by the peak derivation. In this work, the glass transition temperatures were expressed as the mid-point of heat capacity increments.

During the rewarming step, at $-81.3^{\circ} \mathrm{C}$, a change in the heat capacity on the baseline was observed. This baseline shift was related to glass transition temperature $\left(\mathrm{T}_{\mathrm{g}}{ }^{\prime}\right)$ when vitrified water started to decrease its viscosity to values lower than $10^{12}$ $10^{14} \mathrm{~Pa}$. The $\mathrm{T}_{\mathrm{g}}$ ' was closely related to the value found by Curtil et al. (Curtil et al., 1997) who determined the $\mathrm{T}_{\mathrm{g}}$, from pulmonary valves of pigs by DSC and found a decrease in the base line at $83^{\circ} \mathrm{C}$ (Curtil et al., 1997). Also, on the rewarming step, at $-11.6^{\circ} \mathrm{C}$ the ice melting in the tissue was observed (Fig. 2B). The annealing temperature chosen was $-20^{\circ} \mathrm{C}$ and it was based on the values observed in Figure 2.

An increase of just $3^{\circ} \mathrm{C}$ was observed after the annealing step for the bovine pericardium (Fig. 3). Even after the thermal treatment within the above conditions, the $\mathrm{T}_{\mathrm{g}}$ ' did not increase sufficiently to permit an optimal freeze-drying cycle.

Various experiments were conducted using freezedrying microscopy to observe the collapse temperature of the tissue but, probably due to the physical characteristics of the sample, no sign of loss was observed on the tissue structures. Just the crystallization temperature in the sample could be observed, and during the drying step the product reached $0^{\circ} \mathrm{C}$ without any change in it.

Sample weight influences the shape of the transitions as melting, crystallization, and glass transition temperature baseline change. 


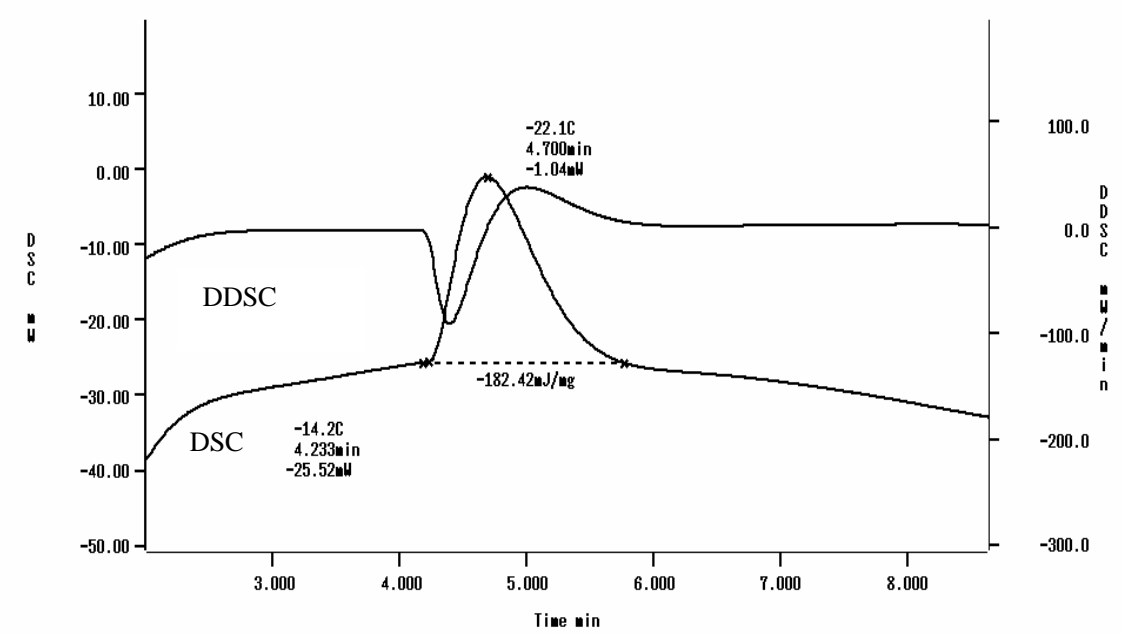

A

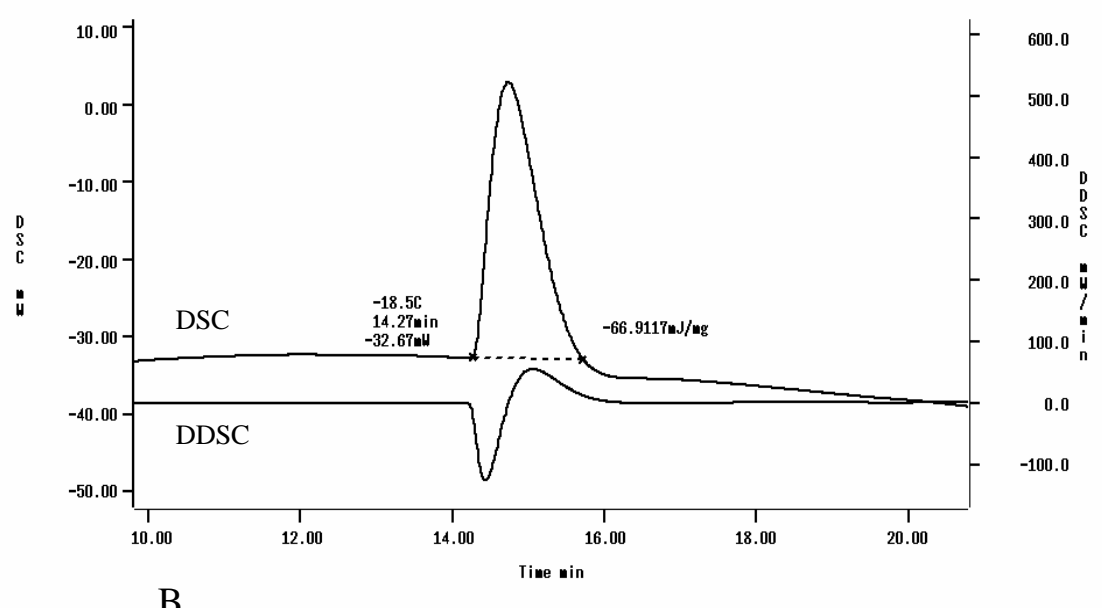

Figure 1 - DSC and DDSC curves of a bovine pericardium tissue. The tissue had been cooled at $2^{\circ} \mathrm{C} / \mathrm{min}(\mathrm{A})$ and $30^{\circ} \mathrm{C} / \mathrm{min}(\mathrm{B})$ and the scan recorded during warming at $5^{\circ} \mathrm{C} / \mathrm{min}$.

The times required for these transitions are longer for larger samples because a greater amount of heat has to be transferred. As a result of this, the peaks are shifted to higher temperatures. For comparison purposes, the measurement of samples of similar weight is recommended. Samples that are too large are disadvantageous because the peaks and baseline changes become broad (lower resolution) and non-uniform peaks lead to irregularly shaped DSC curves. The thickness of the bovine pericardium samples was the same as the original thickness of heart valves manufactured and it was standard for all samples. After some experiments trying to increase the samples weight and thickness, a non-uniform and poor definition of transitions on the DSC curves of pericardium tissue, was observed.

The loss of hydration water from a protein can cause serious alterations both on the structural and conformational state. These alterations can impact the biofunctionallity of the protein. To understand the impact of freeze-drying on the water removal of a protein, it is very important to analyze the secondary structure and its correlation to the drying process itself. Raman spectroscopy was used to determine the secondary structure alteration after freeze-drying bovine pericardium tissue. It has long been used for quantification and qualitative analysis of protein secondary structure in any state (i.e. aqueous, frozen, dried and 
rehydrated) and for studies of stress-induced alterations in protein conformation. This methodology is completely objective and alterations in component bandwiths, which are due to protein unfolding are easily interpreted in the
Raman spectrum by the analysis of Amide I, II and III band (Bussianl and Sander, 1989; Griebenow and Klibanov, 1995; Constantino et al., 1996; Gniadecka et al., 1998).

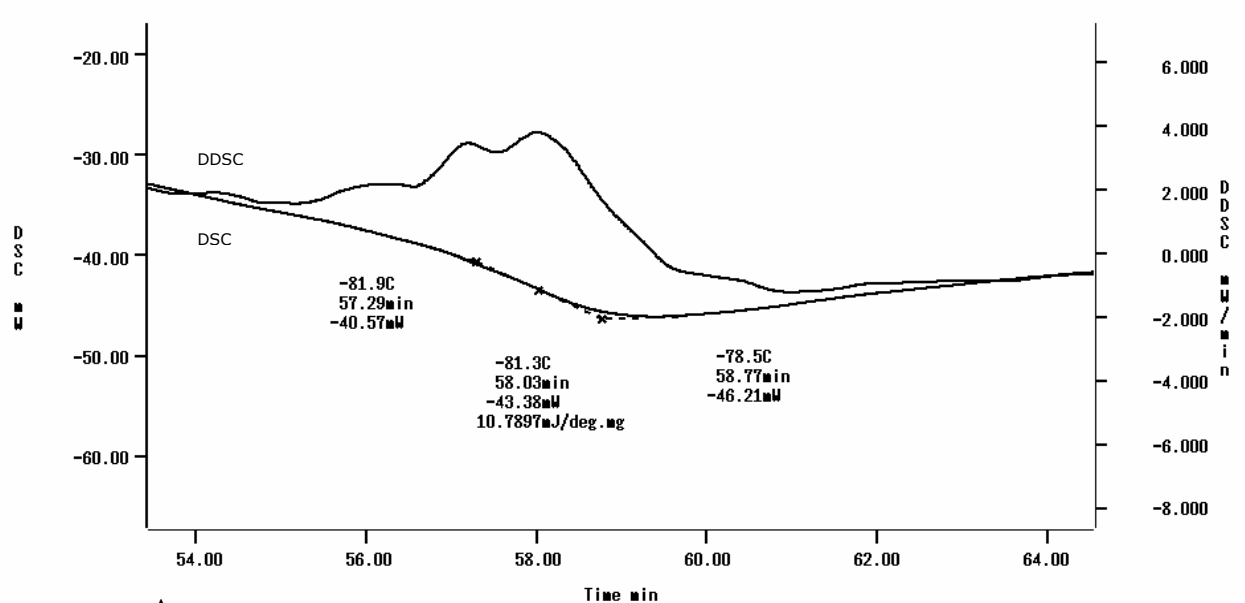

A

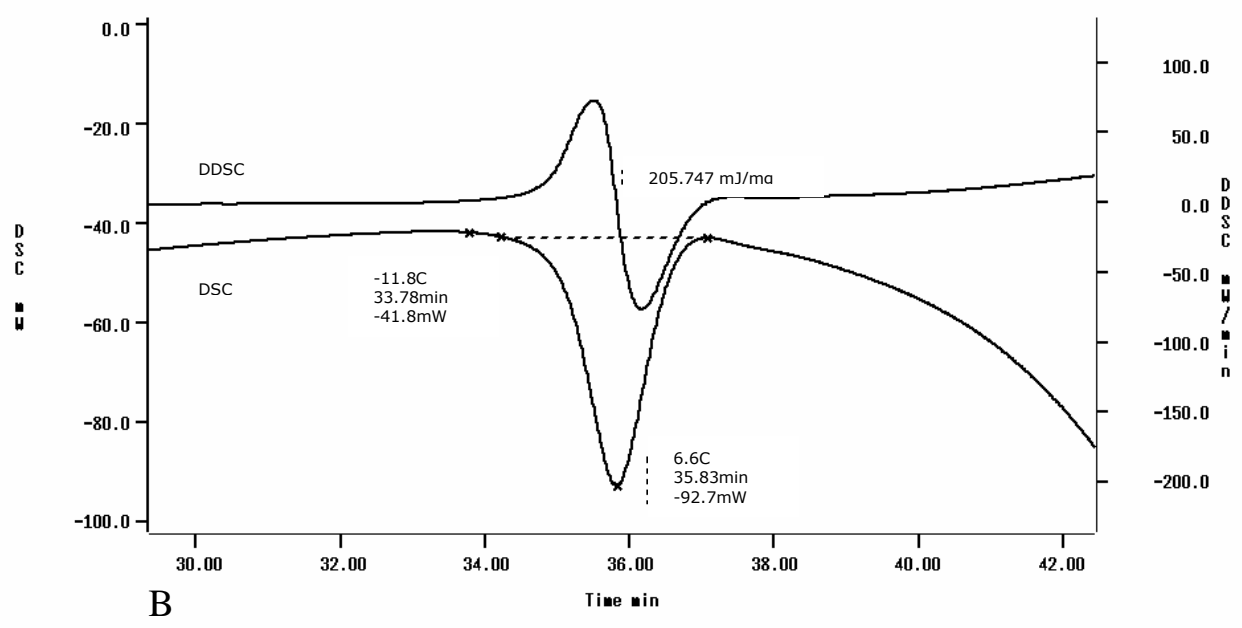

Figure 2 - DSC and DDSC curves of a bovine pericardium tissue. The tissue had been warmed at $5^{\circ} \mathrm{C} / \mathrm{min}$. (A) $\mathrm{Tg}^{\prime}$ at $-81.3^{\circ} \mathrm{C}$; (B) Ice melting temperature at $-11.6^{\circ} \mathrm{C}$.

Fig. 4 shows the structural alterations of native bovine pericardium after freeze-drying under two different freezing protocols: $2^{\circ} \mathrm{C} / \mathrm{min}$ and $30^{\circ} \mathrm{C} / \mathrm{min}$. There were alterations both in the intensities and positions of the Raman spectrum peaks. Considerable alterations on the intensity were observed at $939 \mathrm{~cm}^{-1}$, a peak position related to the $\mathrm{C}$-C $\alpha$-helix stretch. Also, at $1004 \mathrm{~cm}^{-1}$, the intensity of the peak was changed. This peak was related to the $\mathrm{C}-\mathrm{C}$ phenylalanine group.
According to Leikin et al. (1997), this peak was related to the loss of bulk water from the collagen structure.

The Amide III band also showed alterations on the peak intensities from 1240 to $1250 \mathrm{~cm}^{-1}$ due to the $\mathrm{C}-\mathrm{C}$ stretch from the $\alpha$-helical collagen I type. The Amide I band showed significant alterations on the intensity regarding the different freezing protocols during the freeze-drying process. The freezedrying-induced spectral alterations in the 
conformationally sensitive Amide I region are due to protein unfolding and not simply to the loss of water from the protein. The intrinsic effects of water removal on the vibrational properties of the peptide bond, and hence protein spectra were found to be insignificant by Prestrelski et al. (1993).

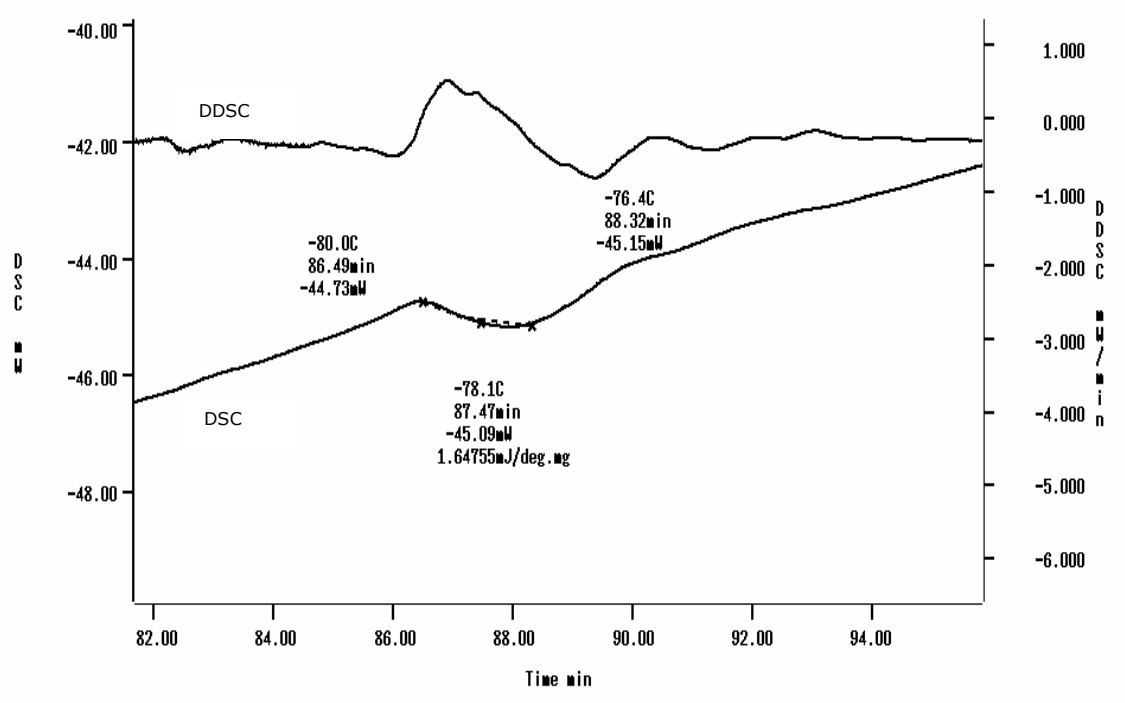

Figure 3 - DSC and DDSC curves of the bovine pericardium tissue. The tissue had been annealed to $-20^{\circ} \mathrm{C}$ for 1 hour. The $\mathrm{T}_{\mathrm{g}}{ }^{\prime}$ after the thermal treatment was increased to $-78.1^{\circ} \mathrm{C}$.

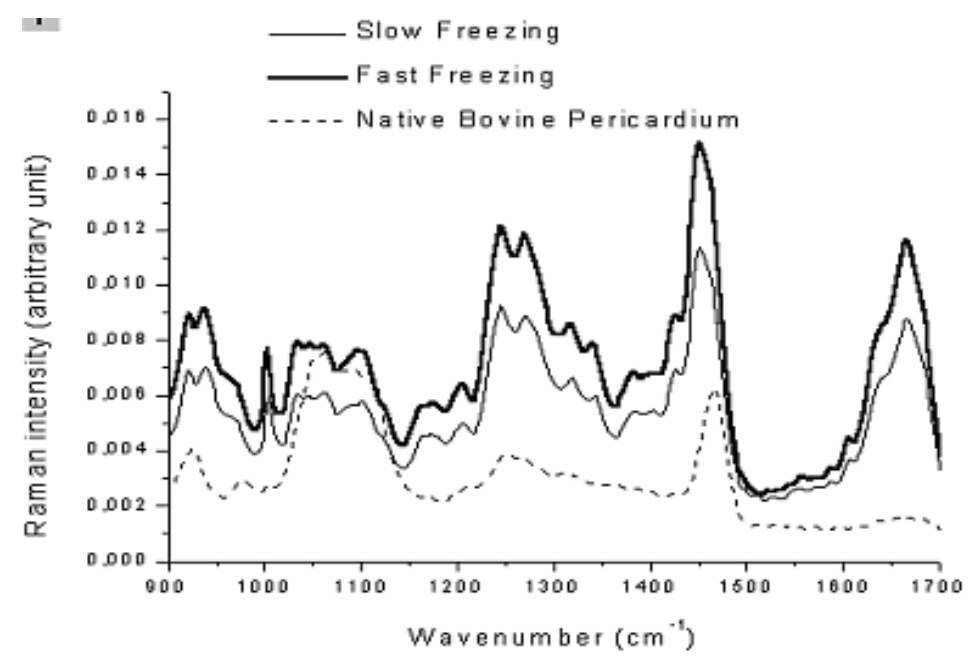

Figure 4 - Raman spectrum of freeze-dried native bovine pericardium under two different freezing rates. Slow freezing $\left(2^{\circ} \mathrm{C} \cdot \mathrm{min}^{-1}\right)$ and fast freezing $\left(30^{\circ} \mathrm{C} \cdot \mathrm{min}^{-1}\right)$. 
Fig. 5 compared the effect of thermal treatment (annealing) on the bovine tissue secondary structure. It was observed that annealing during slow freezing protocol maintained the Amide III band $\left(1241-1272 \mathrm{~cm}^{-1}\right)$ related to the C-N stretch and preserved the $\mathrm{CH}_{3}-\mathrm{CH}_{2}$ binding formation. Also, the maintenance of the peptide carbonyl stretching on the Amide I band $\left(1655-1667 \mathrm{~cm}^{-1}\right)$ was noticed.

Fig. 6 shows the differences of the freeze-drying time using different freezing protocols. The annealing step decreases the freeze-drying time for the samples submitted to the slow freezing and increases the freeze-drying time for the samples which used fast freezing protocol. The thermal treatment was responsible for the reduction on the drying time due to the increasing on the size and distribution of ice crystals. These changes in the interstitial frozen region alter the sublimation rate on the material (Searles et al., 2001).

Fig. 6 also showed (by dew point datas) that freeze-drying using slow freezing without annealing was the unique freeze-drying run which showed secondary drying. Probably, this behavior occurred due to the large amount of glassy water formed between the ice crystals in the interstitial region compared to the other freeze-drying runs.
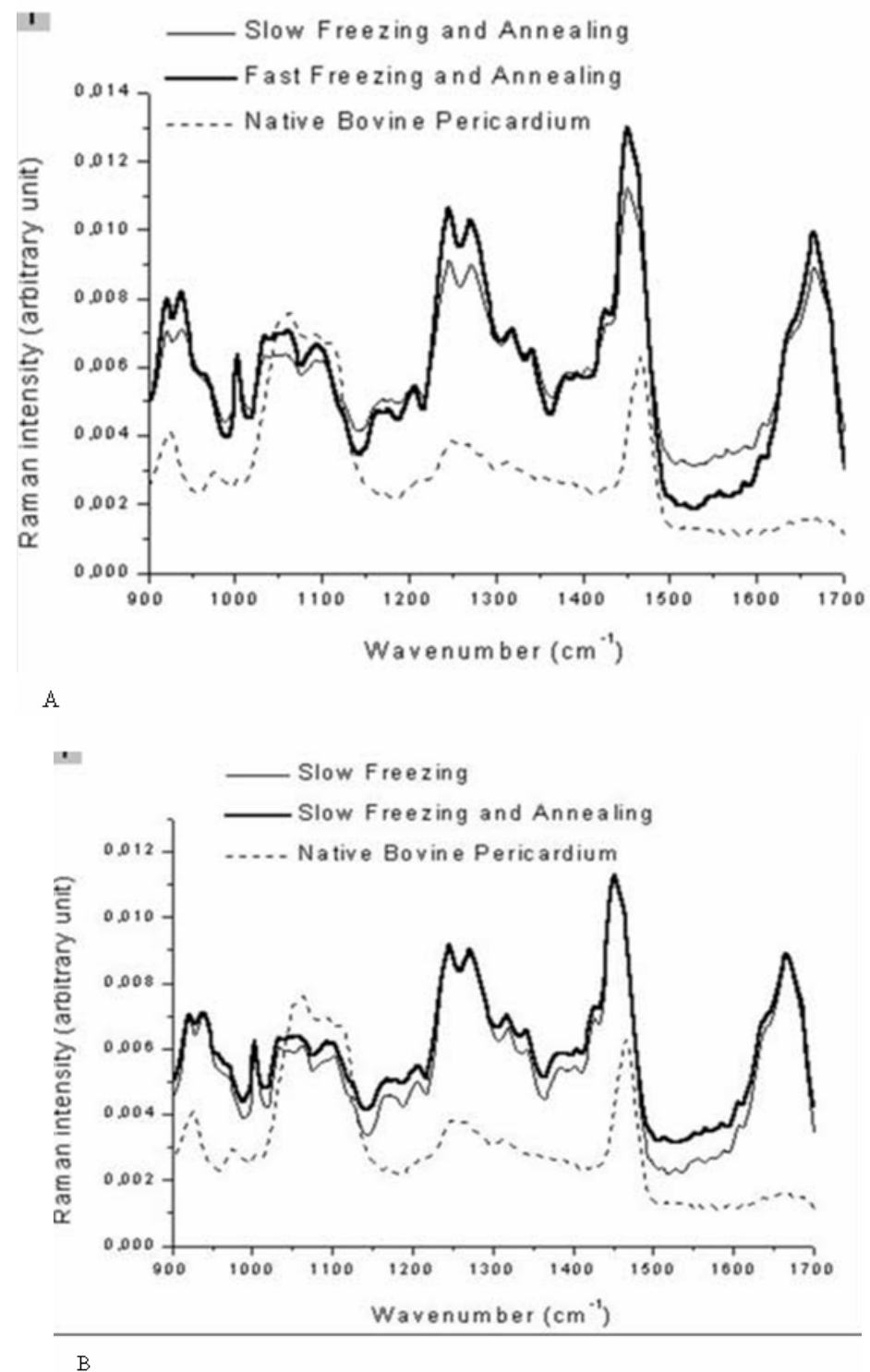

Figure 5 - Raman spectrum of freeze-dried native bovine pericardium under two different freezing rates. (A) Slow freezing and annealing $\left(2^{\circ} \mathrm{C} \cdot \mathrm{min}^{-1}\right)$ and fast freezing and annealing $\left(30^{\circ} \mathrm{C} \cdot \mathrm{min}^{-1}\right)$, (B) Slow freezing and slow freezing and annealing. 

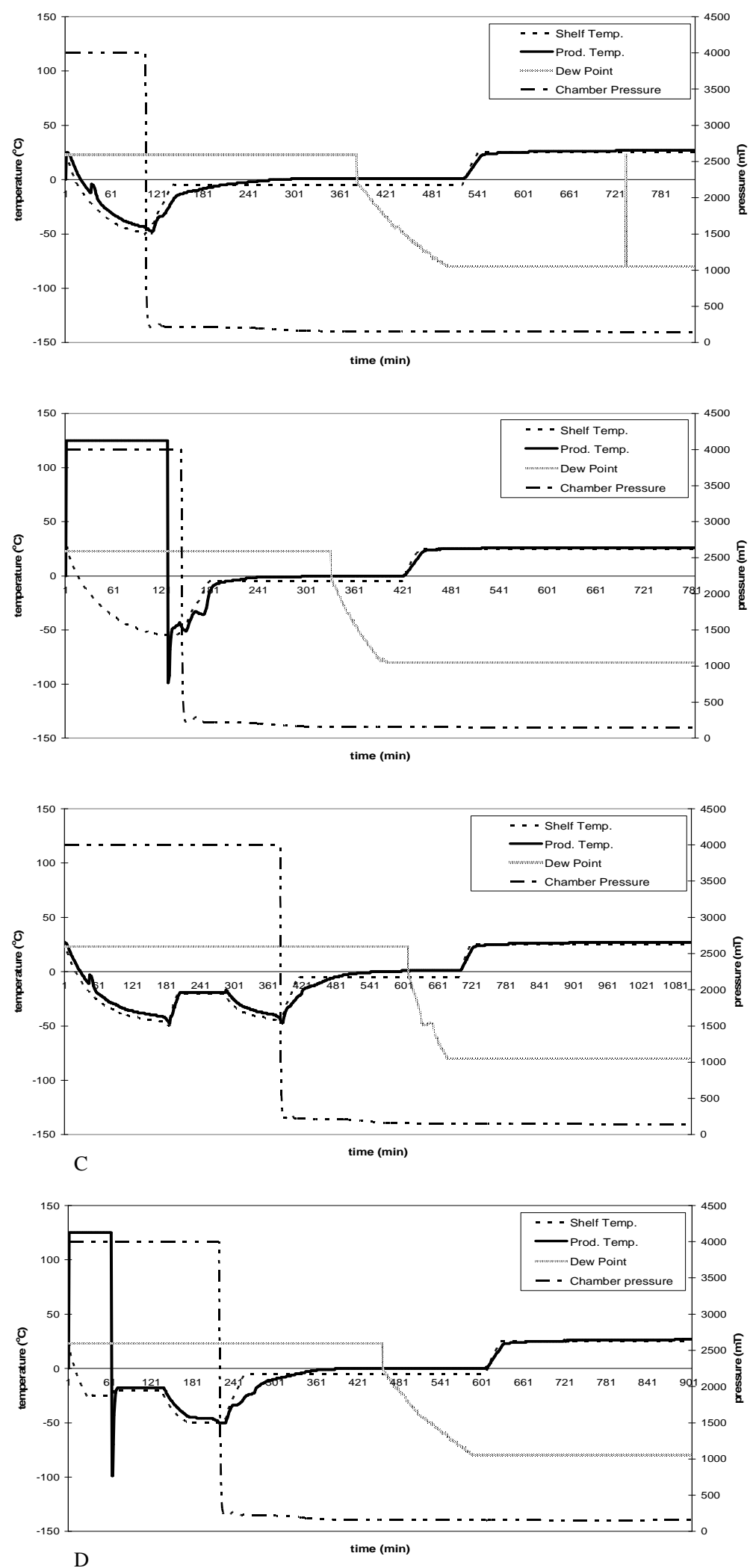

Figure 6 - Freeze-drying curves of bovine pericardium using different freezing protocols. (A) slow freezing $\left(2^{\circ} \mathrm{C} / \mathrm{min}\right)(\mathrm{B})$ fast freezing $\left(30^{\circ} \mathrm{C} / \mathrm{min}\right)$, (C) slow freezing and annealing, (D) fast freezing and annealing. 
Table 1 compares the water content of the freezedried tissues under different freezing protocols. It was observed that freeze-dried samples submitted to slow freezing, with or without annealing, presented lower values (6\%) than freeze-dried samples submitted to fast freezing, with or without annealing (8-10\%).

Comparing all freeze-drying protocols used in this work, the slow freezing with annealing presented greater results than the other protocols. It maintained the secondary structure mainly on the Amide I and III bands, presented the shortest freeze-drying cycle and the lowest water content in the tissue, optimizing the storage conditions. However, the annealing step using the conditions cited was not enough to increase the Tg' of the maximally freeze-concentrated tissue. Even when freeze-drying parameters (shelf temperature and chamber pressure) were above the glass transition temperature of the product it did not show any sign of collapse.

It was shown that bovine pericardium tissue had enough physical support to avoid the shrinkage during the freeze-drying above maximal product temperature in the primary drying.

Hence, it could be concluded that freeze-drying would not damage bovine pericardium structure and consequently the performance of bovine pericardium freeze-dried as a biomaterial.

Table 1 - Freeze-dried bovine pericardium water content values.

\begin{tabular}{cccc}
\hline \multicolumn{3}{c}{ Water content (\%) } \\
\hline Slow freezing $^{*}$ & Fast freezing $^{*}$ & Slow freezing and annealing ${ }^{*}$ & Fast freezing and annealing $^{*}$ \\
\hline $6.64 \pm 0.42$ & $8.67 \pm 0.32$ & $6.54 \pm 0.28$ & $9.47 \pm 0.42$ \\
${ }^{*} \mathrm{n}=10$. & & &
\end{tabular}

\section{ACKNOWLEDGEMENTS}

The authors are grateful to FAPESP (The State of Sao Paulo Research Foundation) and to $\mathrm{CNPq}$ (The National Council for Scientific and Technological Development) for the financial support.

\section{RESUMO}

O pericárdio bovino é um material utilizado na fabricação de biopróteses. A liofilização é um método de secagem que vem sendo estudado para a conservação de válvulas cardíacas. A preservação das características do biomaterial é de fundamental importância no bom funcionamento das válvulas. Este artigo é a primeira etapa do desenvolvimento do ciclo de liofilização do pericárdio bovino. Liofilização é o processo de secagem no qual a água é removida do material congelado por sublimação e desorção da água incongelável, sob pressão reduzida. O congelamento influencia o tamanho do cristal de gelo e, consequentemente, a secagem primária e secundária. $\mathrm{O}$ objetivo deste estudo foi verificar a influência das taxas de congelamento nos parâmetros de liofilização do pericárdio bovino. Determinou-se a temperatura de transição vítrea e o comportamento estrutural do pericárdio bovino liofilizado. Determinou-se o tempo da secagem primária e secundária. $\mathrm{O}$ protocolo de liofilização utilizando-se congelamento lento com annealing apresentou os melhores resultados.

\section{REFERENCES}

Abdelwahed, W.; Degobert G. and Fessi H. (2006), Freeze-drying of nanocapsules: Impact of annealing on the drying process. Int. J. Pharm., 324, 74-82.

Aimoli C. G.; Nogueira G. M.; Nascimento L. S.; Baceti A.; Leirner A. A.; Maizato M. J. S.; Higa O. Z.; Polakiewicz B.; Pitombo R. N. M. and Beppu M. M. (2007), Lyophilized bovine pericardium treated with a phenethylamine-diepoxide as an alternative to preventing calcification of cardiovascular bioprosthesis: preliminary calcification results. Artificial Organs, 31, $278-283$.

Biazus, J. P. M.; Souza, A. G. S.; Santana, J. C. C.; Souza, R. R. S. and Tambougi, E. B. (2005), Optimization of drying process of Zea mays malt to use as alternative source of amylolytics enzymes. Braz. Arch. Biol. Technol., 48, 185-190. 
Bussianl, B. M. and Sander, C. (1989), How to determine protein secondary structure in solution by raman spectroscopy: Practical guide and test case DNase I. Biochem., 28, 4271-4277.

Buttafoco, L.; Engbers-Buijtenhuijs, P.; Poot, A. A.; Dijkstra, P. J.; Daamen, W. F.; Van Kuppevelt, T. H.; Vermes, I. and Feijen, J. (2006), First steps towards tissue engineering of small-diameter blood vessels: Preparation of flat scaffolds of collagen and elastin by means of freeze drying. J. Biomed. Mater. Res. B Appl. Biomater., 77, 357-368.

Chaikof, E. L. (2007), The development of prosthetic heart valves - lessons in form and function. N. Eng. J. Med., 357, 1368-1371.

Chang, B. S. and Randall, C. S. (1992), Use of subambient thermal analysis to optimize protein lyophilization. Cryobiology, 29, 632-656.

Costantino, H. R.; Schwendeman, S. P.; Griebenow, K.; Klibanov, A. M. and Langer, R. (1996), The secondary structure and aggregation of lyophilized tetanus toxoid. J. Pharm. Sci., 85, 1290-1293.

Curtil, A.; Pegg, D. E. and Wilson, A. (1997), Freeze drying of cardiac valves in preparation for cellular repopulation. Cryobiology, 34, 13-22.

Doillon C. J.; Whyne, C. F.; Brandwein, S. and Silver F. H. (1986), Collagen-based wound dressings: Control of the pore structure and morphology. $J$. Biomed. Mater. Res. A, 20, 1219-1228.

Faraj, K. A.; Van Kuppevelt, T. H. and Daamen, W. F. (2007), Construction of collagen scaffolds that mimic the three-dimensional architecture of specific tissues. Tissue Eng., 13, 2387-2394.

Frushour, B.G. and Koenig, J. L. (1975), Raman scattering of collagen, gelatin, and elastin. Biopolymers, 14, 379-391.

Griebenow, K. and Klibanov A. M. (1995), Lyophilization-induced reversible changes in the secondary structure of proteins. Proc. Natl. Acad. Sci. USA, 92, 10969-10976.

Gniadecka M.; Nielsen, O. F.; Wessel, S.; Heidenheim, M.; Christensen, D. H. and Wulf, H. C. (1998), Water and Protein Structure in Photoaged and Chronically Aged Skin. J. Invest. Dermatol., 111, 1129-1132.

Hawe, A. and Friess, W. (2006), Impact of freezing procedure and annealing on the physico-chemical properties and the formation of mannitol hydrate in mannitol-sucrose-NaCl formulations. Eur. J. Pharm. Biopharm., 64, 316-325.

James N. L.; Poole-Warren L. A.; Schindhlem B. K.; Mitchell R. M.; Mitchell R. E. and Howlett C. R. (1991), Comparative evaluation of treated bovine pericardium as a xenograft for hernia repair. Biomaterial, 12, 801-809.
Jastrzebska M.; Wrzalik R.; Kocot A.; ZalewskaRejdak J. and Cwalina B. (2003), Hydration of glutaraldehyde-fixed pericardium tissue: Raman spectroscopic study. J. Raman Spectrosc., 34, 424431.

Jennings, T. A. (1999), Lyophilization - Introduction and Basic Principles. Interpharm Press, Denver.

Leikin S.; Parsegian V. A.; Yang W. H. and Walrafen G. E. (1997), Raman spectral evidence for hydration forces between collagen triple helices. Proc. Natl. Acad. Sci. USA, 94, 11312-11317.

Levine, H. and Slade, L. (1988), Principles of "cryostabilization" technology from structure/ property relationships of carbohydrate/ water systems - A review., Cryo-Lett., 9, 21-63.

Maizato M. J.; Higa O. Z.; Mathor M. B.; Camillo M. A.; Spencer P. J.; Pitombo R. N.; Zavaglia C. A. and Leirner A. A. (2003), Glutaraldehyde-treated bovine pericardium: effects of lyophilization on cytotoxicity and residual aldehydes. Artif. Organs., 27, 692-694.

Mello, K. G. P. C.; Bernusso, L. C.; Pitombo, R. N. M. and Polakiewicz, B. (2006), Synthesis and physicochemical characterization of chemically modified chitosan by succinic anhydride. Braz. Arch. Biol. Technol., 49, 665-668.

Nail, S. L.; Jiang, S.; Chongprasert, S. and Knopp, S. A. (2002), Fundamentals of freeze-drying. InDevelopment and Manufacture of Protein Pharmaceutical, ed. S. L. Nail and M. J. Akers. Kluwer Academic Publishers/Plenum Press, New York, pp. 281-360.

Naimark W. A.; Lee J. M.; Limeback H. and Cheung D. T. (1992), Correlation of structure and viscoelastic properties in the pericardia of four mammalian species. Am. J. Physiol., 262, 1095-1106.

O’Brien, F. J.; Harley, B. A.; Yannas, I. V. and Gibson, L. (2004), Influence of freezing rate on pore structure in freeze-dried collagen-GAG scaffolds. Biomaterials, 25, 1077-1086.

Patapoff T. W. and Overcashier D. E. (2002), The importance of freezing on lyophilization cycle development. Biopharm., 3, 16-21.

Pikal, M. J. and Shah, S. (1990), The collapse temperature in freeze drying: Dependence on measurement methodology and rate of water removal from the glassy phase. Int. J. Pharm, 62, 165-186.

Prestrelski, S. J.; Tedeschi, N.; Arakawa, T. and Carpenter, J. F. (1993), Dehydration-induced conformational changes in proteins and their inhibition by stabilizers. Biophys. J., 65, 661-671. 
Searles J. A.; Carpenter J. F. and Randolph T. W. (2001), Annealing to optimise the primary drying rate, reduce freeze-induced drying rate heterogeneity, and determine $\underline{T}_{\mathrm{g}}^{\prime}$ in pharmaceutical lyophilization. $J$. Pharm. Sci., 90, 872-887.

Spiro T. G. (1988), Biological Applications of Raman Spectroscopy, vol. II. John Wiley and Sons Inc, New Walton, A.; Deveney, M. and Koenig, J. L. (1970), Raman spectroscopy of calcified tissue. Calcified Tissue Int., 6,162-167.
Webster, D. A. and Werner F. W. (1983), Mechanical and functional properties of implanted freeze-dried flexor tendons. Clin. Orthop. Relat. Res., 180, 301309.

Received: December 04, 2007; Revised: July 17, 2008; Accepted: April 14, 2009. 